\title{
GAMBARAN KEKUATAN TEKAN BAHAN TUMPATAN SEMEN IONOMER KACA YANG DIRENDAM DALAM MINUMAN BERALKOHOL
}

\author{
${ }^{1}$ Vanessa M. Roeroe \\ ${ }^{2}$ Dinar A. Wicaksono \\ ${ }^{3}$ Juliatri \\ ${ }^{1}$ Kandidat SkripsiProgram Studi Pendidikan Dokter Gigi Fakultas Kedokteran \\ Universitas SamRatulangiManado \\ ${ }^{2}$ Program Studi Pendidikan Dokter Gigi Fakultas Kedokteran \\ Universitas Sam Ratulangi \\ Email: vanessaroeroe@yahoo.com
}

\begin{abstract}
Glass ionomer cement is restorative materials that attached on the enamel and dentin through chemical combination, that consists of powder and liquid. GIC powder and liquid are alumino silikat glass and from poliakrilik acid. Characters of GIC are biocompatible, removing fluoride, prevent developing cariest, esthetic, translucent, low solubility, anti bacterial. Nowadays, aperitif that consumed by people has sour nature and solvent. The purpose of this research is to know description compressive strength transformation of type II GIC that soaked in variant percentage of aperitif. This was an experimental research used post test only control group design. Each samples were 5 for every treat. Sample consisted of Type II SIK materials which soaked during 24 hours in 5\%, 10\%, $40 \%$ aperitif, and aquades as control. Endurance and Strength of Type II GIC measured by compression test device. From research result available that mean of strength GIC measurement which soaked in aperitif 5\%,10\%, 40\%, aquades such as 2,84 MPa, 3,36 MPa, 4,5 MPa, and 2,58 MPa as control variable. Description of this research is transformation of compressive strength GIC increasing if soaked in higher percentage aperitif because sample appication was not yet perfect.
\end{abstract}

Keywords: compressive strength, glass ionomer cement, aperitif

\begin{abstract}
Abstrak: Semen ionomer kaca adalah bahan restorasi yang melekat pada enamel dan dentin melalui ikatan kimia, terdiri dari campuran powder dan liquid. PowderSIK adalah kaca aluminosilikat dan liquid larutan asam poliakrilik. Beberapa sifat yang dimiliki semen ionomer kaca yaitu biokompatibilitas melepas fluor sehingga dapat mencegah karies lebih lanjut, estetis, daya larut rendah, translusen, dan bersifat anti bakteri. Minuman beralkohol yang banyak dikonsumsi masyarakat saat ini mempunyai sifat asam dan sebagai pelarut. Tujuan penelitian ini untuk mengetahui gambaran perubahan kekuatan tekan bahan tumpatan SIK tipe II yang direndam dalam minuman beralkohol dengan berbagai presentase. Penelitian ini merupakan penelitian eksperimental menggunakan post test only control group design. Masing-masing sampel dibuat 5 buah untuk setiap perlakuan. Sampel terdiri atas bahan SIK tipe II yang direndam dengan variasi presentase 5\%,10\%, 40\% alkohol dan aquades sebagai kontrol selama 24 jam. Kekuatan tekan SIK diukur menggunakan alat tes kompresi. Berdasarkan hasil penelitian didapatkan rata-rata pengukuran kekuatan SIK yang direndam dalam alkohol 5\%,10\%, 40\%, dan kontrol aquades masing-masing 2,84 MPa, 3,36 MPa, 4,5 $\mathrm{MPa}, 2,58 \mathrm{MPa}$. Gambaran dari hasil penelitian ini bahwa perubahan kekuatan tekan SIK semakin meningkat apabila direndam dalam kadar minuman beralkohol lebih tinggi karena proses pembuatan sampel SIK belum sempurna.
\end{abstract}

Kata kunci: kekuatan tekan, semen ionomer kaca, minuman beralkohol 
Kemajuan bidang kedokteran gigi mencakup tindakan preventif, kuratif, dan promotif, juga estetik yang menyebabkan kebutuhan terhadap restorasi estetik semakin banyak.Semen ionomer kaca (SIK) merupakan salah satu bahan restorasi yang banyak digunakan dokter gigi karena mempunyai keunggulan berupa ikatan secara khemis dengan gigi, melepas fluor sehingga dapat mencegah karies lebih lanjut, estetis, biokompatibel, daya larut rendah, translusen, dan bersifat anti bakteri. ${ }^{1}$ Penggunaan SIK yang meluas antara lain sebagai bahan perekat, pelapik, bahan restoratif untuk restorasi Kelas I dan II klasifikasi Black. ${ }^{2}$ Restorasi kelas III dan IV tidak dianjurkan menggunakan SIK karena sampai saat ini formulanya masih kurang kuat dan lebih peka terhadap keausan penggunaan jika dibandingkan dengan komposit. ${ }^{1}$ Penelitian lain menyatakan bahwa material ini biokompatibel di dalam rongga mulut, normal ekspansi hampir sama dengan struktur gigi dan perlekatan baik. Keunggulan-keunggulan tersebut membuat bahan tumpatan SIK banyak digunakan oleh dokter gigi. ${ }^{1}$

Para dokter gigi lebih cenderung menggunakan SIK tipe II sebagai bahan tumpatan gigi karena memiliki sifat cukup keras tetapi rapuh, kekuatan tekan relatif tinggi, daya tahan terhadap fraktur dan keausan rendah. Tidak dianjurkan untuk dipakai dalam merestorasi gigi beban besar. Daya tahan yang rendah terhadap keausan dipengaruhi oleh sifat kekuatan tekan permukaan, oleh karena itu dalam penelitian ini pengujian akan dilakukan terhadap kekuatan tekan permukaan SIK. $^{2}$

Dalam kehidupan sehari-hari tidak dapat dipungkiri bahwa terdapat banyak jenis minuman beralkohol di sekitar kita. Seperti di kota Manado banyak masyarakat mengonsumsi minuman beralkohol.Minuman beralkohol diproses melalui pengenceran minuman yang mengandung etanol. ${ }^{3}$ Minuman beralkohol dapat merusak tumpatan pada enamel gigi yang perlahan membuatnya keropos, karena memiliki sifat asam dan sebagai pelarut. Terutama memengaruhi warna dan mengikis enamel gigi karena keasaman dari minuman beralkohol. ${ }^{23}$

Alkohol yang masuk ke dalam tubuh akan mengalami serangkaian proses biokima yang akan dimetabolisme oleh tubuh terutama hati, diubah menjadi asam asetat. Alkohol mempunyai sifat fisika yaitu titik didih, asam, kelarutan dalam air dan sifat sebagai pelarut. Dilihat dari kegunaan alkohol yang memiliki sifat fisik dan kimiawi sebagai pelarut, alkohol dapat menyebabkan kekuatan tekan SIK menurun karena mempunyai sifat sebagai pelarut. ${ }^{4}$ Penelitian sebelumnya yang dilakukan terhadap sejenis tumpatan gigi yaitu resin komposit hybrid, menyatakan bahwa semakin lama waktu perendaman dalam minuman beralkohol kekuatan tekan permukaan tumpatan akan menurun. ${ }^{5}$

Peneliti menggunakan minuman beralkohol (etanol) sebagai bahan penguji kekuatan tekan bahan tumpatan SIK yang dilarutkan ke dalamnya.

\section{METODE PENELITIAN}

Penelitian ini merupakan penelitian deskriptifdengan metode eksperimental laboratories rancangan eksperimental post test only control group design. Penelitian dilaksanakan di Laboratorium Teknik Sipil Fakultas Teknik dan Laboratorium Kimia Fakultas Matematika Ilmu Pengetahuan Alam (MIPA) Universitas Sam Ratulangi ManadoSampel penelitian yaitu 20 sampel SIK yang telah direndam dalam minuman beralkohol dengan presentase 5\%, 10\%, $40 \%$.

Alat dan bahan yang digunakan dalam penelitian ini ialah SIK tipe II (GC Fuji), celluloid strip,glass lab, scalpel, universal testing machine (Shimadzu Autograph tipeG $5000 \mathrm{E})$, minuman beralkohol dengan kadar 5\% (Vodka Mix Max), minuman beralkohol dengan kadar $10 \%$ (Sweet Wine), minuman beralkohol dengan kadar 40\% (Cap Tikus)

Tissue.

Cetakan sampel terbuat dari plastik pipet berbentuk sedotan minuman dengan alas celluloid strip diletakkan di atas glass lab,sebelumnya cetakan bagian dalam telah dioleskan vaseline. Bubuk dan cairan diaduk 
di atas mixing pad dengan perbandingan 3 : 6 (sesuai dengan aturan pabrik $=2,7: 1,0 \mathrm{~g}$ ), kemudian dimasukkan ke dalam cetakan sampel. Bagian atas cetakan diberi celluloid strip ditekan dengan beban $1 \mathrm{~kg}$ sampai mengeras (15 menit), dimasukkan dalam wadah tertutup selama 24 jam lalu sampel dilepaskan dari cetakan.Lokasi pembuatan sampel di Fakultas MIPA Universitas Sam Ratulangi Manado.

Sampel dibagi dalam empat kelompok berdasarkan perlakuan perendamannya di dalam gelas ukur yaitu minuman beralkohol dengan presentase 5\%, 10\%, 40\%, dan aquades.Masing-masing dituang sebanyak $100 \mathrm{ml}$ dalam setiap gelas ukur pada tiap kelompok,kemudian memasukkan sampel ke dalam gelas ukur tiap kelompok, dan direndam selama 24 jam. Setelah direndam 24 jam sampel dikeringkan dengan tissue lalu disimpan di cawan petri, selanjutnya dibawa ke laboratorium Fakultas Teknik Sipil Universitas Sam Ratulangi Manado.

Setiap sampel yang akan diuji diletakkan di atas tatakan di dalam Universal Testing Machine. Selanjutnya ditekan dengan ukuran crosshead spead $0,5 \mathrm{~mm} /$ menit dan load $250 \mathrm{KgF}$ hingga sampel fraktur. Pada monitor akan tertera daya kekuatan tekan yang dihasilkan (Mpa).

\section{HASIL PENELITIAN}

Hasil cetakan sampel SIK berbentuk silinder dengan ukuran 5 x $4 \mathrm{~mm}$ (diameter $\mathrm{x}$ tinggi ) didiamkan dalam wadah tertutup selama 24 jam. Proses pengukuran tekanan pada sampel SIK dilakukan setelah sampel SIK direndam dalam konsentrasi alkohol $5 \%, 10 \%, 40 \%$, dan aquades sebagai kontrol selama 24 jam. Jumlah sampel SIK yang digunakan dalam penelitian ini yaitu 5 (lima) buah untuk setiap kelompok perlakuan. Uji kekuatan tekan dilakukan dengan menggunakan alat tes kompresi hingga sampel SIK hancur. Hasil kekuatan tekan sampel akan terlihat pada skala yang tertera pada layar alat tes kompresi.

Hasil pengukuran tekanan pada sampel SIK setelah direndam dalam berbagai alkohol terlihat dalam Tabel 1 .
Tabel 1. Distribusi hasil pengukuran sampel SIK yang direndam dalam presentase alkohol

\begin{tabular}{ccccc}
\hline & \multicolumn{4}{c}{ Jenis Perlakuan } \\
\cline { 2 - 5 } Pengujian & $\begin{array}{c}\text { Aquades } \\
(\mathrm{Mpa})\end{array}$ & $\begin{array}{c}\text { Alkohol } \\
5 \% \\
(\mathrm{Mpa})\end{array}$ & $\begin{array}{c}\text { Alkohol } \\
10 \% \\
(\mathrm{Mpa})\end{array}$ & $\begin{array}{c}\text { Alkohol } \\
40 \% \\
(\mathrm{Mpa})\end{array}$ \\
\hline I & 1,8 & 1,7 & 2,5 & 2,4 \\
II & 1,9 & 2,7 & 2,7 & 3,2 \\
III & 2,6 & 3,1 & 3,5 & 4,9 \\
IV & 3,2 & 3,2 & 3,6 & 5,7 \\
V & 3,4 & 3,5 & 4,5 & 6,3 \\
\hline
\end{tabular}

Data pada Tabel 1 menunjukkan bahwa hasil pengukuran tekanan tertinggi sampel SIK yaitu pada perendaman dalam konsentrasi alkohol $40 \%$ dan hasil pengukuran tekanan terendah yaitu pada perendaman dalam aquades sebagai kontrol.

Hasil rata-rata uji tekanan sampel SIK yang direndam dalam alkohol 5\%, 10\%, $40 \%$ dan aquades dalam satuan Mega Paskal (MPa) dapat dilihat pada Tabel 2.

Tabel 2. Hasil rata-rata pengukuran sampel SIK

\begin{tabular}{cc}
\hline Jenis Perlakuan & $\begin{array}{c}\text { Hasil rata-rata Uji } \\
\text { Tekanan (Mpa) }\end{array}$ \\
\hline Alkohol 5\% & 2,84 \\
Alkohol 10\% & 3,36 \\
Alkohol 40\% & 4,5 \\
Aquades & 2,58 \\
\hline
\end{tabular}

Data di atas menunjukkan bahwa hasil pengukuran tekanan pada sampel SIK yang direndam dalam aquades memiliki nilai yang paling kecil.Peningkatan hasil terjadi ketika sampel SIK direndam dalam alkohol. Hasil kekuatan tekan rata-rata sampel SIK yang direndam dalam alkohol pada konsentrasi 5\%, 10\%, 40\%, dan aquades masing- masing 2,84 $\mathrm{MPa}, 3,36 \mathrm{MPa}, 4,5 \%$ $\mathrm{MPa}$, dan 2,58 MPa.

\section{BAHASAN}

Semen ionomer kaca mempunyai komposisi bahan powderacid soluable calcium fluoraluminosilicate glass dan liquidaqueous solution of polyacrilycacid. Kandungan fluorida pada bahan ini sangat tinggi yang berfungsi untuk menurunkan 
suhu fusi kaca, meningkatkan kekuatan dan translusensi semen. ${ }^{1,2}$ Keuntungan SIK yaitu perlekatan ionik permanen terhadap struktur gigi dan kapasitas untuk melepaskan fluorida. ${ }^{1}$ Semen ionomer kaca memiliki biokompabilitas yang baik terhadap jaringan gigi, solubilitas rendah, antikariogenik, perubahan dimensi kecil dan tahan terhadap fraktur. ${ }^{4}$ KerugianSIK antara lain estetik, kehalusan permukaan, kekuatan kompresif, kekuatan flexural kurang dibandingkan kompomer dan juga lebih tidak tahan terhadap erosi. ${ }^{6}$ Minuman beralkohol mempunyai sifat asam dan sebagai pelarut, sehingga dapat mengikis tumpatan dan memengaruhi warna enamel gigi. ${ }^{7}$

Alkohol (ROH) dan eter (ROR) terbagi atas Dietil eter (eter) digunakan sebagai pematirasa (anesthetic), etanol (alkohol) digunakan dalam minuman keras.Propanol (isopropyl akohol atau alkohol gosok) digunakan sebagai zat pembunuh kuman (bakteriosida).Metanol (metil alkohol atau alkohol kayu, (komponen utama dalam spiritus), digunakan sebagai bahan bakar dan pelarut. Dalam laboratorium dan industri, semua senyawa ini digunakan sebagai pelarut dan pereaksi. ${ }^{3}$

Alkohol mempunyai sifat fisika yaitu titik didih, kelarutan dalam air, sifat sebagai pelarut.Dalam ilmu kimia, alkohol atau alkanol adalah istilah yang umum untuk senyawa organik yang memiliki gugus hidroksil (-OH) yang terikat pada atom karbon itu sendiri dan juga terikat pada atom hidrogen atau atom karbon yang lain. ${ }^{7}$ Alkohol digunakan secara luas dalam industri dan ilmu pengetahuan sebagai pereaksi, pelarut, dan bahan bakar. ${ }^{3}$

Lama waktu dalam penelitian ini yaitu 24 jam penyimpanan wadah tertutup, dan 24 jam perendaman dalam minuman beralkohol. Sampel yang digunakan pada penelitian ini adalah paket powder dan liquid SIK konvensional tipe II. Sampel direndam dalam minuman beralkohol konsentrasi 5\%, 10\%, 40\% dan aquades sebagai kontrol.Minuman beralkohol yang digunakan pada penelitian ini yaitu Vodka MixMax, Sweet Wine, dan Cap Tikus.

Pengujian kekuatan tekan dilakukan untuk mengetahui pengaruh daya tahan kekuatan tekan setelah direndam dalam berbagai konsentrasi minuman beralkohol.Kekuatan SIK berubah menjadi lebih besar ketika direndam dalam alkohol dengan konsentrasi lebih tinggi.

Kekuatan tekan merupakan salah satu faktor yang memengaruhi kekerasan dan abrasinya suatu material. ${ }^{8}$ Jika kekuatan tekan bertambah, maka kekuatan tekan dan ketahanan material terhadap abrasi ikut bertambah. Sama seperti dengan kekuatan tekan, kekuatan tekan dan ketahanan suatu material terhadap abrasi juga bertambah jika material tersebut berada pada kondisi yang kering. ${ }^{9}$

Perendaman sampel SIK dalam berbagai presentase alkohol menjelaskan bahwa daya tahan kekuatan dan tekanan SIK menjadi lebih tinggi.Sampel SIK bereaksi dengan alkohol yang direndam.Semakin tinggi presentase alkohol yang digunakan maka kekuatan tekan SIK lebih meningkat.Pada hasil sampel SIK yang direndam dalam aquades sebagai kontrol, kekuatan tekanterendah dibandingkan direndam dalam berbagai presentase alkohol.

Penelitian ini menggambarkan perubahan tingkat kekuatan tekan dan ketahanan SIK setelah direndam dalam presentase 5\%, 10\%, $40 \%$ alkohol dan aquades sebagai variabel kontrol.Dalam penelitian lain menyatakan bahwa alkohol berpengaruh pada kekuatan tekan permukaan bahan tumpatan komposit. ${ }^{5}$

Dari hasil penelitian yang diperoleh penggunaan SIK setelah direndam dalam berbagaipresentase alkohol mengalami peningkatankekuatan tekannya setelah diukur melalui alat uji tekan.Hasil penelitian diperoleh perbedaan rata-rata hasil pengukuran kekuatan tekan pada sampel SIK.

Tabel hasil tekanan SIK memperlihatkan rata-rata pengukuran kekuatan SIK yang dilarutkan dalam alkohol presentase 5\%, $10 \%, 40 \%$, dan aquades masing- masing 2,84; 3,36; 4,5 dan 2,58 MPa. Hasil tekanan memperlihatkan bahwa peningkatan nilai terjadi ketika sampel SIK direndam dalam 
alkohol dengan konsentrasi semakin tinggi. Dari hasil tersebut terlihat bahwa nilai perubahan terbesar yaitu pada sampel SIK yang direndam selama 24 jam dalam minuman beralkohol Cap Tikus 40\%. Dalam kelompok aquades memiliki hasil rata-rata terendah yaitu 2,58 $\mathrm{MPa}$ dibandingkan dengan direndam dalam minuman beralkohol.

Teori menyatakan bahwa alkohol mempunyai sifat fisika yaitu titik didih, asam, kelarutan dalam air dan sifat sebagai pelarut. Dilihat dari kegunaan alkohol yang memiliki sifat fisik dan kimiawi sebagai pelarut, alkohol dapat menyebabkan kekuatan tekan SIK menurun karena mempunyai sifat sebagai pelarut. ${ }^{3}$ Hasil kekuatan tekan pada penelitian ini berbanding terbalik dengan teori. Dalam penelitian ini gambaran hasil kekuatan tekan sampel SIK meningkat karena mengalami beberapa faktor penyebab selama proses pembuatan sampel. Pada saat proses pembuatan sampel, cetakan SIK terbuat dari plastik pipet elastis meyebabkan bentuk sampel SIK tidak silinder sempurna. Volume cetakan sampel tidak semua sama karena pengaruh di saat pencampuran bubuk dan cairan yang berbeda-beda. Jarak pemberian cairan di atas bubuk SIK tidak semua sama, sehingga hasil cetakan sampel tidak homogen dengan baik dan tidak berbentuk silinder dengan sempurna.

Dilihat gambaran data tersebut menunjukkan bahwa kadar presentase minuman beralkohol yang digunakan dalam perendaman, memengaruhi kekuatan tekan sampel SIK. Dari data terlihat bahwa makin tinggi kadar konsentrasi minuman beralkohol yang digunakan, maka makin besar nilai hasil pengukuran kekuatan tekan pada sampel SIK.Peningkatan hasil pengukuran kekuatan tekan dipengaruhi oleh waktu perendaman sampel SIK dalam minuman beralkohol, penyimpanandalam wadah tertutup selama 24 jam, proses pembuatan cetakan sampel SIK. Dalam penelitian ini perendaman dalam berbagai presentase minuman beralkohol mempengaruhi kekuatan tekan sampel SIK.
Alkohol yang digunakan dalam penelitian ini berasal dari minuman Sweet Wine, Vodka, Cap Tikus bukan dari alkohol murni $5 \%, 10 \%$, dan $40 \%$.

Jadi kemungkinan bahwa SIK yang digunakan dalam penelitian ini kekuatan tekannya bertambah keras, karena kandungan komposisi selain dari minuman tersebut.Proses pembuatan cetakan sampel yang tidak sempurna dan tidak homogen dengan baik juga mempengaruhi hasil kekuatan tekanSIK. Cetakan sampel SIK juga mempengaruhi hasil akhir kekuatan tekan, karena bentuk cetakan yang sempurna sangat diperlukan dalam proses pembuatan sampel.

\section{SIMPULAN}

Berdasarkan penelitian yang telah dilakukan maka dapat disimpulkan sebagai berikut :

1. Dilihat gambaran terjadi perubahan daya tahan kekuatan tekan SIK setelah direndam alkohol konsentrasi 5\%, 10\%, $40 \%$ dan aquades sebagai kontrol.

2. Perendaman SIK dalam alkohol dengan konsentrasi 5\%, 10\%, 40\% dapat meningkatkan kekuatan tekan bahan tumpatan.

3. Proses pembuatan cetakan sampel tidak sempurna mempengaruhi hasil akhir kekuatan tekan SIK.

\section{SARAN}

Dapat mempertimbangkan untuk tidak mengkonsumsi alkohol walau daya tahan kekuatan tekan SIK meningkat dalam bidang ilmu kedokteran gigi karena alkohol tidak baik bagi tubuh secara umum.

Pada penelitian ini diharapkan dapat menjadi pedoman atau data awal untuk dilakukan penelitian lanjutan.

Disarankan untuk dilakukan penelitian selanjutnya dengan menggunakan komposisi alkohol murni berbagai konsentrasi.

\section{DAFTAR PUSTAKA}

1. Annusavice KJ. Buku Ajar Ilmu Bahan Kedokteran Gigi, ed. 10. Jakarta: EGC; 2004: p. 449-79. 
2. Meizarini A, Irmawati. Kekuatan tekan Permukaan Semen Ionomer Kaca Konvensional Tipe II Akibat Lama Penyimpanan. Dental Journal 2005; 38, p. 146-50.

3. Fessenden RJ, Fessenden JS, Pudjaatmaka AH. Kimia Organik, ed.2. 2005; p. 272-5

4. Wildian. Rancang Bangun Alat Ukur Kadar Alkohol Pada Cairan Menggunakan Sensor mq-3 Berbasis Mikrokontroler at89s51. Jurnal fisika unand 2013; 2(1) : p. 13-9.

5. Wulandari R. Pengaruh Etanol 0-5\% Terhadap Kekuatan tekan Permukaan Resin Komposit Hybrid. Medan; 2011; p. 5-15.
6. Puspitasari DA, Meizarini A, Munadziroh E. Penambahan Kitosan pada Cairan Semen Ionomer Kaca Terhadap Kekuatan Tekan Hancur. Material dental journal 2013; 4(2) : p. 67-70.

7. Utina SS. Alkohol dan Pengaruhnya Terhadap Kesehatan Mental. Gorontalo; 2004; 5(2): p. 1-9

8. Noort VR. Introduction to Dental Materials, ed, 2. 2013: p. 113-5

9. Bresciani E, Terezinha DJEB, Fagundes TC, Akimi A, Terrin MM, Maria FDL. Compressive and Diametral Tensile Strength of Glass Ionomer Cements. Journal of applied oral science 2004 Dec; 12(4): p. 1-8. 